\title{
Advanced Stripper Gas Produced Water Remediation
}

Quarterly Technical Report for the Period Ending 03/31/2001

\section{Western SynCoal, LLC}

Ray W. Sheldon, P.E.

September 2001

Grant DE-FG26-00NT40965

Western SynCoal, LLC

P.O. Box 7137

Billings, MT 59103-7137 


\section{TABLE OF CONTENTS}

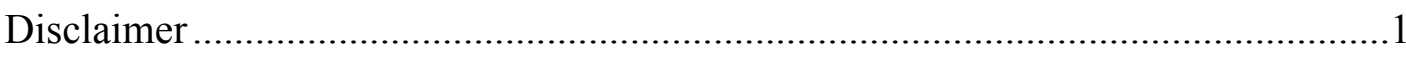

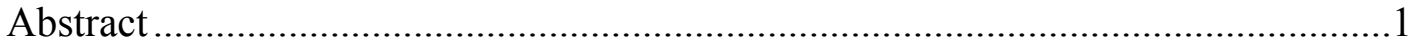

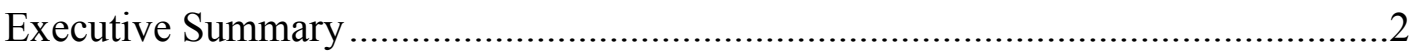

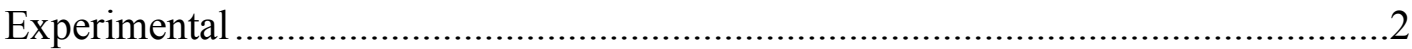

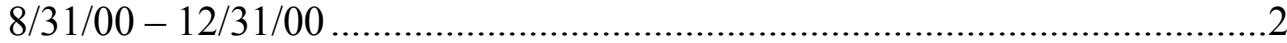

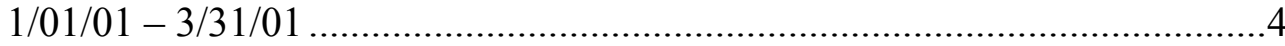

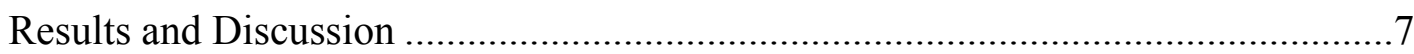



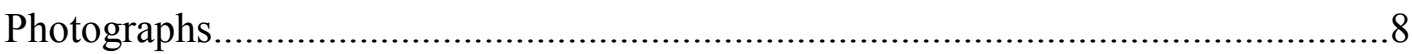

\section{LIST OF TABLES AND FIGURES}

Preliminary Column Test ......................................................................................

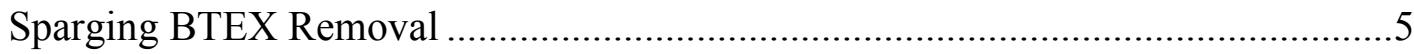

Lifetime Efficiency of the Initial Test Column.......................................................6

\section{APPENDIX}

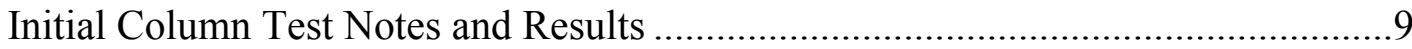

Preliminary Laboratory Results .........................................................................

Second Test Series Results Using Initial Column Filters ........................................12 
This report was prepared as an account of work sponsored by an agency of the United States Government. Neither the United States Government nor any agency thereof, nor any of their employees, makes any warranty, express or implied, or assumes any legal liability or responsibility for the accuracy, completeness, or usefulness of any information, apparatus, product, or process disclosed, or represents that its use would not infringe privately owned rights. Reference herein to any specific commercial product, process, or service by trade name, trademark, manufacturer, or otherwise does not constitute or imply its endorsement, recommendation, or favoring by the United States Government or any agency thereof. The views of authors expressed herein do not necessarily state or reflect those of the United States Government or any agency thereof.

\begin{abstract}
Natural gas and oil production from stripper wells also produces water contaminated with hydrocarbons, and in most locations, salts and trace elements. The hydrocarbons are not generally present in concentrations that allow the operator to economically recover these liquids. Produced liquids, (Stripper Gas Water) which are predominately water, present the operator with two options; purify the water to acceptable levels of contaminates, or pay for the disposal of the water.
\end{abstract}

The project scope involves testing SynCoal as a sorbent to reduce the levels of contamination in stripper gas well produced water to a level that the water can be put to a productive use. Produced water is to be filtered with SynCoal, a processed sub-bituminous coal. It is expected that the surface area of and in the SynCoal would sorb the hydrocarbons and other contaminates and the effluent would be usable for agricultural purposes.
Test plan anticipates using two well locations described as being disparate in the level and type of contaminates present. The loading capacity and the rate of loading for the sorbent should be quantified in field testing situations which include unregulated and widely varying liquid flow rates. This will require significant flexibility in the initial stages of the investigation.

The scope of work outlined below serves as the guidelines for the testing of SynCoal carbon product as a sorbent to remove hydrocarbons and other contaminants from the produced waters of natural gas wells. A maximum ratio of $1 \mathrm{lb}$ carbon to $100 \mathrm{lbs}$ water treated is the initial basis for economic design. While the levels of contaminants directly impact this ratio, the ultimate economics will be dictated by the filter servicing requirements. This experimental program is intended to identify those treatment parameters that yield the best technological practice for a given set of operating conditions. The goal of this research is to determine appropriate guidelines for field trials by accurately characterizing the performance of SynCoal over a full range of operating conditions. 


\section{Executive Summary}

Work completed in this reporting period included a second series of filtration tests and air sparging of the filtered produced water to test the ability to further reduce lighter weight hydrocarbon contents. The actual filtration tests were run on twelve (12) selected days between February 1 and 20. The filtering process was typically operated for 6-8 hour period during each day with samples taken near the end of the processing period. These tests used the same SynCoal column that was originally employed in the November testing. The column pressure remained constant throughout the test and the flowrate was held steady at a little over two gallons per minute. Analyses indicated that the hydrocarbon retention was reduced substantially from the initial test although the water clarity continued to appear greatly improved at the column discharge. Major ions and trace metals were largely unaffected during the testing. Air sparging of the filtered water showed remarkable removal of BTEX constituents and appears to be promising.

Work completed from August 31, 2000 through December 31, 2000 included construction of test columns and support facilities to conduct the preliminary scoping trials to process produced water with SynCoal. The construction, installation, column packing and acquisition of water to be treated required three weeks of effort. The actual test runs ran two consecutive days of constant flow at a rate of approximately three gallons per minute. Three gallons per minute is similar to the rate of water production from the majority of wells in the DenverJulesberg (D-J) basin. A single SynCoal column with $104 \mathrm{lbs}$ of media was employed for this preliminary test. The column pressure remained constant throughout the test period. Analysis indicated good hydrocarbon retention on the SynCoal averaging $90 \%$ or better removal from the produced water. Water clarity was observed to be greatly improved at the column discharge. Major ions and trace metals were largely unaffected by exposure to SynCoal.

\section{Experimental}

\section{8/31/2000 through 12/31/2000}

After a prototype "filter canister" was designed and fabricated from steel pipe, the project team decided to construct the test units from six inch PVC pipe and fittings and mount them on portable angle iron skid mounted stands to simplify construction, modification and installation. NARCo's Wattenberg shop and lab buildings were cleaned out to provide work space near the production field. In October 2000, fabrication of a two stage filter unit constructed of schedule 40 PVC pipe and related fittings was completed. Initially, some difficulty was encountered in preventing the migration of coal particles from the canister but after trying several screen / packing materials the filter retained the coal without losing particles with the water flow. The filter unit is mounted in an angle iron frame which can be easily be modified to provide an insulated shed around the filter unit with an access door in front. With the filter unit housed in an insulated structure coupled with a small catalytic heater, this unit should prove to 
be functional in winter as well as summer.

The filter unit was installed into a single state separator at the Ione \#11 production battery in an effort to evaluate the functionality of the unit under field conditions. While the unit was determined to be of the correct design for generic connection to a separator unit, the surge discharge pressure of the single stage unit at the Ione battery was greater than anticipated $(+200$ psig). In order to use the PVC filter unit on locations with pressures in excess of 50 psig, a surge tank is needed to control the impact force of the water discharged to the filter unit.

The filter unit was moved back to the Wattenberg location where it was installed with a surge feed tank, a pump to supply a steady flow to the filter and a "clean" water tank to characterize the filter. The initial testing was conducted on November 1 and 2, 2000 with water flowing through the filter for approximately 12 hours at a 3.0 to 3.5 gpm rate. Pre-treatment and posttreatment water samples were collected and analyzed. It appeared from visual observation of the pre-treatment and post-treatment water samples that the filter unit is removing insoluble and colloidal particulates in the produced water being treated. The analyses indicated that the oil and grease content was reduced from an average of over $36.8 \mathrm{mg} / \mathrm{l}$ to under $2.4 \mathrm{mg} / \mathrm{l}$, approximately 93 percent reduction. Total suspended solids were reduced from $59 \mathrm{mg} / \mathrm{l}$ in the initial sample to under $20 \mathrm{mg} / \mathrm{l}$ on average. Copper and silver concentrations appeared to be reduced as well. Unfortunately, the sodium, calcium, magnesium and potassium concentrations did not appear to be affected.

\section{Preliminary Column Test}

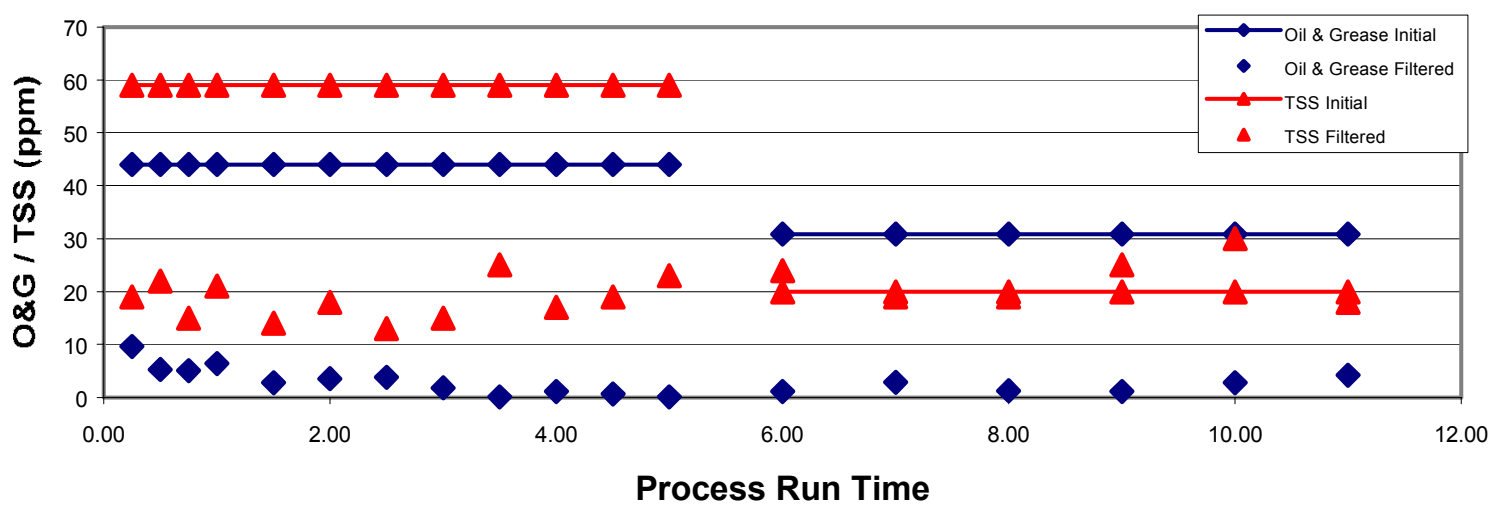


$01 / 01 / 2001$ through $03 / 31 / 2001$

In reviewing the data, it was postulated that the remaining oil and grease concentration was primarily light hydrocarbons that could be removed by simple air sparging. Additionally, concepts of using SynCoal with a high limestone content as the filter media may enhance the removal of the dissolved salt mineral content. Further testing to determine the filter material's saturation point, if the high limestone content SynCoal would remove more the the dissolved solids and if the remaining oil and grease levels can be removed by air sparging was determined to be an appropriate next step.

In late January, work was completed to winterize the test filter unit and a 110 volt $3 / 4$ h.p. electric centrifugal pump with a by-pass system and a 1 inch brass Neptune water meter with totalization capabilities were installed.

A second series of flow tests were conducted on the $1^{\text {st }}$ stage of the prototype canister filter unit. The primary objective of this test series was to determine the point of climax or saturation of the filter media.
From February 2 to February 20, the unit was tested in 6-8 hour sequences on 12 individual days. During that test period, 3 different batches of untreated water were received at the test facility and processed through the filter unit. A total of 10,520 gallons of produced water was processed through the stage one filter at an average inlet pressure of 10 psig and an average flow rate of 133.5 gallons per hour or $2.23 \mathrm{gpm}$. A sample of the treated and untreated water was collected initially and at the end of the first days' run; and at the end of each days run thereafter. The samples were placed in glass jars and labeled. As the attached data indicates, each new batch of untreated water presented a different set of organic concentrations. In an attempt to minimize the impact of this fluctuation in the chemical makeup of the water, the sample protocol for this phase of testing provided for the collection of a "in or untreated" sample at the beginning of the daily flow test and an "out or treated" sample at the ending of the daily flow test. The water quality changed with each new batch of untreated water. The following is a brief summary of the organic concentration.

\begin{tabular}{|c|c|c|c|c|}
\hline Sample ID & $\begin{array}{c}\text { Untreated Oil \& } \\
\text { Grease } \\
\text { ppm }\end{array}$ & $\begin{array}{c}\text { Treated Oil \& } \\
\text { Grease ppm }\end{array}$ & $\begin{array}{c}\text { Untreated } \\
\text { BTEX } \\
\text { ppb }\end{array}$ & $\begin{array}{c}\text { Treated } \\
\text { BTEX } \\
\text { ppb }\end{array}$ \\
\hline 01-Feb & 182 & 117 & 261 & 99 \\
\hline 02-Feb & 106 & 79.2 & 1165 & 1476 \\
\hline $05-\mathrm{Feb}$ & 100 & 42 & 1255 & 1177 \\
\hline 06-Feb & 118 & 15.7 & 1539 & 881 \\
\hline 07-Feb & 258 & 403 & 1096 & 671 \\
\hline 07-Feb & 179 & 140 & 1214 & 883 \\
\hline 08-Feb & 255 & 239 & 3161 & 1907 \\
\hline 09-Feb & 276 & 251 & 1129 & 2522 \\
\hline $12-\mathrm{Feb}$ & 175 & 141 & 3757 & 2441 \\
\hline
\end{tabular}




\begin{tabular}{|c|c|c|c|c|}
\hline Sample ID & $\begin{array}{c}\text { Untreated Oil \& } \\
\text { Grease } \\
\text { ppm } \\
\end{array}$ & $\begin{array}{l}\text { Treated Oil \& } \\
\text { Grease ppm }\end{array}$ & $\begin{array}{c}\text { Untreated } \\
\text { BTEX } \\
\text { ppb } \\
\end{array}$ & $\begin{array}{c}\text { Treated } \\
\text { BTEX } \\
\text { ppb } \\
\end{array}$ \\
\hline 13-Feb & 12.6 & 17.1 & 1796 & 1976 \\
\hline 13-Feb & 4.1 & 8.3 & 2959 & 2773 \\
\hline 14-Feb & 4.2 & 3.8 & 2218 & 4293 \\
\hline 19-Feb & 4.3 & 8.2 & 7587 & 7853 \\
\hline 20-Feb & 2.8 & 2 & 7749 & 7203 \\
\hline
\end{tabular}

\begin{tabular}{|l|r|r|r|r|r|r|}
\hline Sample ID & $\begin{array}{c}\text { Untreated Oil } \\
\text { \& Grease } \\
\text { ppm }\end{array}$ & $\begin{array}{c}\text { Treated Oil } \\
\text { \& Grease } \\
\text { ppm }\end{array}$ & $\begin{array}{c}\text { Removal } \\
\text { Efficiency }\end{array}$ & $\begin{array}{c}\text { Untreated } \\
\text { BTEX } \\
\text { ppm }\end{array}$ & $\begin{array}{c}\text { Treated } \\
\text { BTEX } \\
\text { ppm }\end{array}$ & $\begin{array}{c}\text { Removal } \\
\text { Efficiency }\end{array}$ \\
\hline Batch 1 Ave & 126.5 & 63.5 & $50 \%$ & 1055 & 908 & $14 \%$ \\
\hline Batch 2 Ave & 228.6 & 234.8 & $-3 \%$ & 2071 & 1685 & $19 \%$ \\
\hline Batch 3 Ave & 5.6 & 7.9 & $-41 \%$ & 4462 & 4820 & $-8 \%$ \\
\hline
\end{tabular}

As part of the second stage testing protocol, the treated water from the filter unit was placed in a 100 barrel steel water tank recently removed from an operating production facility. The tank was not cleaned prior to use in this test in an effort to maintain realistic field conditions. An air sparging unit was fabricated and air at 20 psig continuous flow was sparged through approximately 80 barrels of treated water.

\begin{tabular}{|l|c|c|c|c|c|}
\hline \multicolumn{1}{|c|}{ Sample ID } & $\begin{array}{c}\text { Benzene } \\
(\mathbf{p p b})\end{array}$ & $\begin{array}{c}\text { Toluene } \\
(\mathbf{p p b})\end{array}$ & $\begin{array}{c}\text { Ethylbenzene } \\
(\mathbf{p p b})\end{array}$ & $\begin{array}{c}\text { m.p Xylene } \\
(\mathbf{p p b})\end{array}$ & $\begin{array}{c}\text { o-xylene } \\
(\mathbf{p p b})\end{array}$ \\
\hline Initial Sample & 2550 & 1520 & 28.5 & 272 & 117 \\
\hline $5^{\text {th }}$ Day Sample & 33.2 & 35.5 & 12.8 & 6.0 & 8 \\
\hline $11^{\text {th }}$ Day Sample & $<0.4$ & 2.4 & 2.0 & 0.4 & $<0.4$ \\
\hline
\end{tabular}

\section{Sparging BTEX Removal}

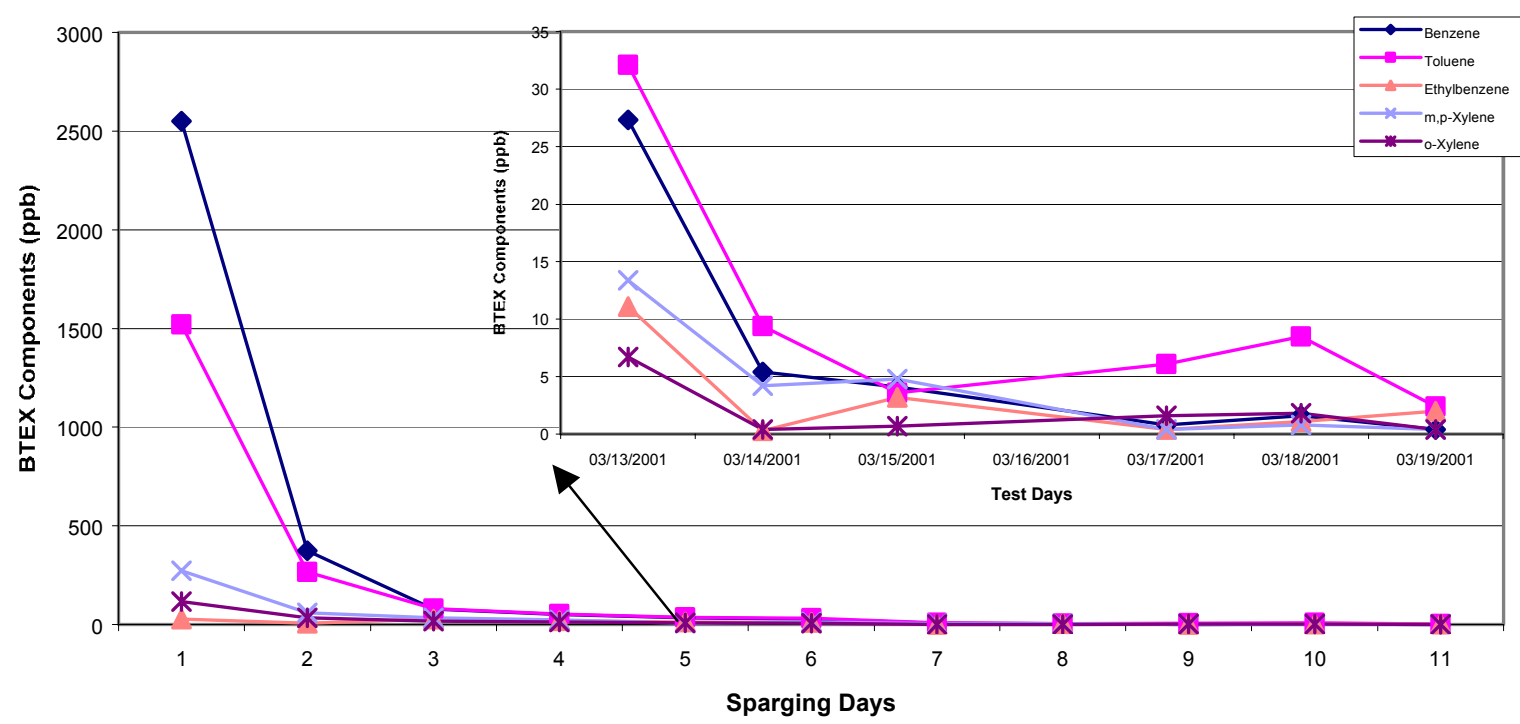


This data indicates a dramatic decrease in the BTEX concentration of the treated water in a very short period of time and under less than ideal conditions (cold temperatures and limited venting of the tank). Air sparging was conducted from the morning of February 27 through the evening of March 3 when the air sparging operation was suspended after the $5^{\text {th }}$ day pending test results. After receiving the data, the air sparging tests were continued beginning March 13, 2001 and concluding March 19, 2001.

The second series of BTEX analysis on the 80 barrel batch of filtered and sparged produced water was completed and the results indicate that air sparging of the water filtered by a single stage of the test filter unit has removed all of the benzene and o-xylene with only a trace of the toluene, ethylbenzene, and m,p,xylene all concentrations of which are well below any action levels.

The inorganic test data is confusing with regard to the effects the filtering process has on the inorganics in the water sampled. Of the salts, the sodium and potassium numbers are significant and appear to increase. Heavier metal seems to be decreased. The remaining inorganic numbers are insignificant. This raises the possibility that the treated water, once subject to air sparging to remove the VOC's could be recycled as makeup water for frac jobs or drilling fluids.

\section{Lifetime Efficiency of the Initial Test Column}

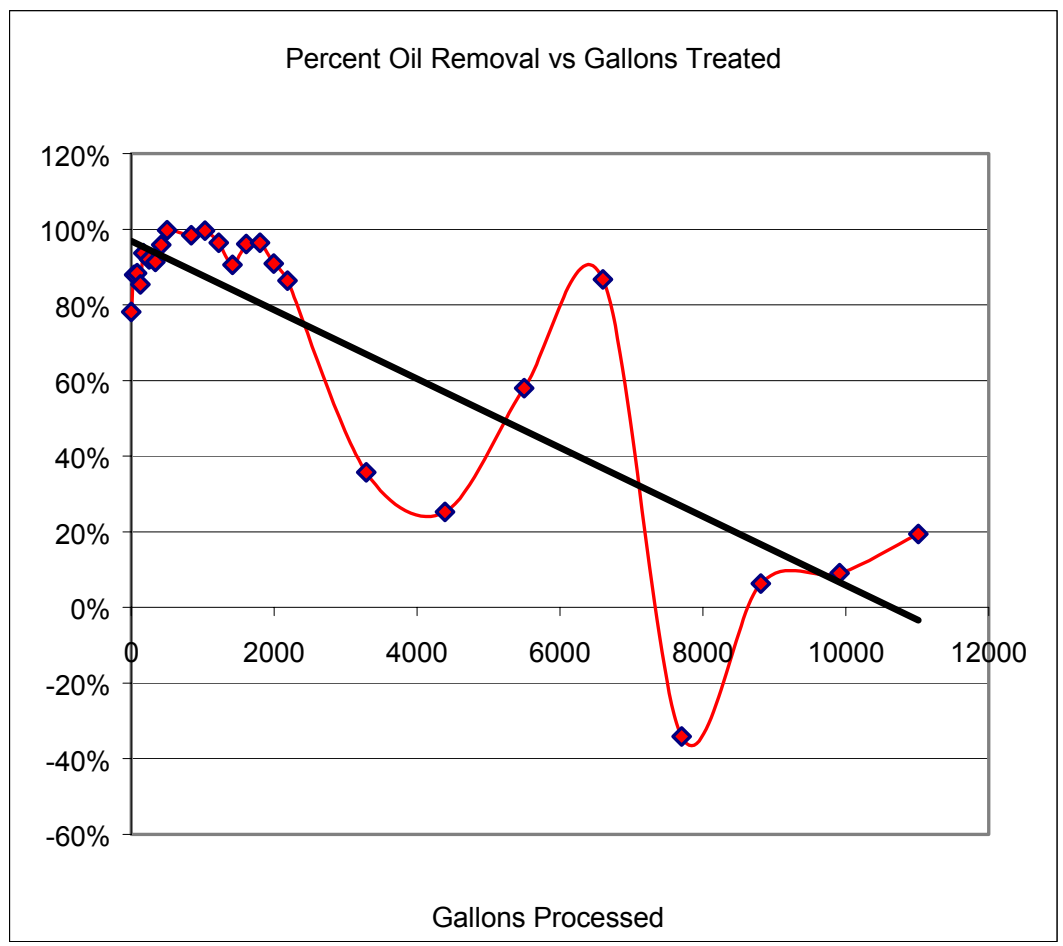




\section{Results and Discussion}

The testing during this period used the same filter and media as used in the initial testing. This filter media has been sitting unused for approximately 90 days since the last testing was concluded. The produced water treated came in three batches each with different organic concentrations. The first batch had substantially higher organic concentrations than the initial work in November and filters efficiency was much lower than the initial work indicated which could have been a result of the filter having a loading which started to effect its efficiency. Although looking at the data, it appears the final portion of this batch the filter was more efficient than the initial portion.

The second batch was even higher in organic concentration and it appeared that the filter had reached its saturation point as the untreated and treated water samples were effectively the same in oil and grease concentration for both the second and third batch of produced water.

The BTEX appeared to be generally unchanged throughout the range of samples from untreated to treated and generally increased in concentration with each batch processed. The inorganic analyses from samples taken on February 7 indicate that the sodium, potassium, calcium, magnesium, zinc, and manganese percentages concentrations were increased probably due to the leaching of the inorganic material within the filter media. The concentrations of iron, copper, cadmium, and lead were decreased at least theoretically due to the reaction with the filter material. The theory that the organic material that was not being captured was lighter hydrocarbons, seems to be well worn out by the air sparging test work and the reduction in Betex material concentration over very short periods of time as a result of air sparging.

\section{Conclusions}

The SynCoal filter media can be effective in removing oil and grease until it becomes saturated at which point its effectiveness is reduced. It is possible that the filters effectiveness was impacted by the long layoff and some subsequent reaction of the previously loaded oil and grease on the carbon material or further oxidation of the carbon as it sat for the prolonged period of time in the filter.

The organic material that escapes the filter media appears to be lighter weight hydrocarbons that can be effectively removed by air sparging to achieve acceptable levels of hydrocarbon concentration.

Further the effective on dissolved inorganic concentrations is inconclusive although there is apparently leaching of sodium, potassium, calcium and magnesium materials from the filter media.

Further work is necessary to repeat these tests to eliminate the impact of the extended inactive period with the filter and to further define the capacity and limitations of the filter media. 


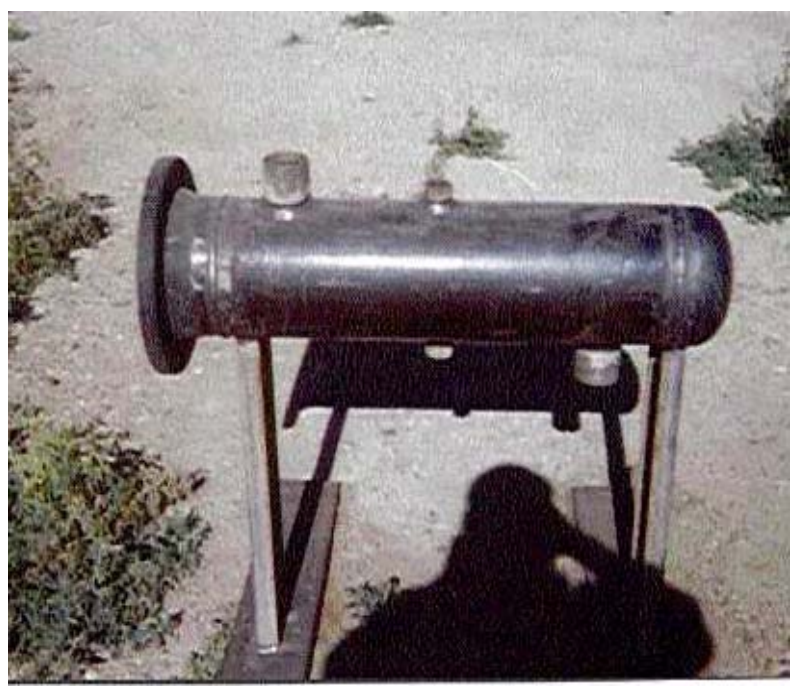

Prototype "Filter Canister"

From Steel Pipe

Filter Unit Installed at Field Site
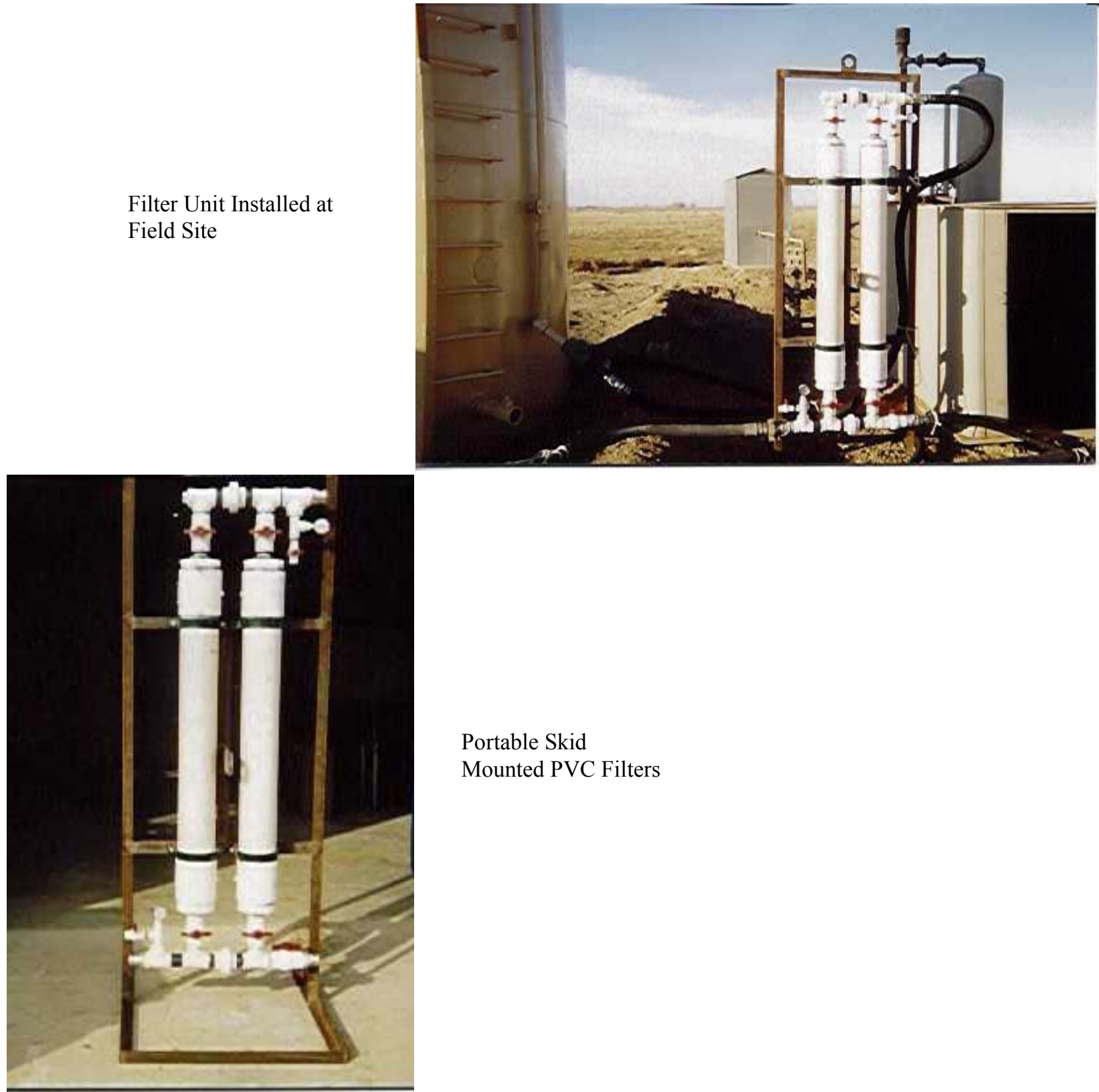

Portable Skid

Mounted PVC Filters 


\section{Initial Column Test Notes \& Results}

Wattenburg Location

Sample Log

ID

NA-001A

NA-001B

NA-001C

NA-002A

$\mathrm{NA}-002 \mathrm{~B}$

NA-002C

NA-003A

NA-003B

NA-003C

NA-004A

NA-004B

NA-004C

NA-005A

NA-005B

NA-005C

NA-006A

NA-006B

NA-006C

NA-007A

NA-007B

NA-007C

NA-008A

NA-008B

NA-008C

NA-009A

NA-009B

NA-009C

NA-010A

NA-010B

NA-010C

NA-011A

NA-011B

NA-011C

NA-012A

NA-012B

NA-012C

NA-013A

NA-013B

NA-013C

Wattenburg Location

NA-014A

NA-014B

NA-014C
Interval Time

0.00

0.00

0.00

0.25

0.25

0.25

0.50

0.50

0.50

0.75

0.75

0.75

1.00

1.00

1.00

1.50

1.50

1.50

2.00

2.00

2.00

2.50

2.50

2.50

3.00

3.00

3.00

3.50

3.50

3.50

4.00

4.00

4.00

4.50

4.50

4.50

5.00

5.00

5.00

0.00

0.00

0.00
SynCoal Water Treatment Test Series 1

Nov. 1,00



SynCoal Water Treatment Test Series 1

Nov. 2, 00

$10: 00$
6.5

2.42

NA-014A,B,C IS INFEED SAMPLE

flow 3.0gpm 


$\begin{array}{llllll}\text { NA-015A } & 1.00 & 11: 00 & 6.5 & 2.35 & \text { inlet 17psi } \\ \text { NA-015B } & 1.00 & & & & \\ \text { NA-015C } & 1.00 & & & & \\ \text { NA-016A } & 2.00 & 12: 00 & 6.5 & 2.30 & \text { flow 3.3gpm } \\ \text { NA-016B } & 2.00 & & & & \\ \text { NA-016C } & 2.00 & & & & \\ \text { NA-017A } & 3.00 & 13: 02 & 6.5 & 2.33 & \text { inlet 17psi } \\ \text { NA-017B } & 3.00 & & & & \\ \text { NA-017C } & 3.00 & & & & \\ \text { NA-018A } & 4.00 & 14: 00 & 6.5 & 2.34 & \\ \text { NA-018B } & 4.00 & & & & \\ \text { NA-018C } & 4.00 & & & & \text { inlet 17psi } \\ \text { NA-019A } & 5.00 & 15: 00 & 6.5 & 2.36 & \text { flow 3.3gpm } \\ \text { NA-019B } & 5.00 & & & & \\ \text { NA-019C } & 5.00 & & & & \\ \text { NA-020A } & 6.00 & 16: 00 & & & \text { Gallons Treated } \\ \text { NA-020B } & 6.00 & & & & \text { Previous day } \\ \text { NA-020C } & 6.00 & & & & \text { Total for single column to date }=\end{array}$

\section{Preliminary Laboratory Results}

Lab Results

Weld Laboratories, Inc.

Lab No: 4287

NA-001 FEED

NA-002

NA-003

NA-004

NA-005

NA-006

NA-007

NA-008

NA-009

NA-010

NA-011

NA-012

NA-013

NA-014 FEED

NA-015

NA-016

NA-017

NA-018

NA-019

NA-020

$\begin{array}{rrr}\text { Oil/Grease } & \mathrm{Ca} & \mathrm{Na} \\ \mathbf{4 4 . 0} & \mathbf{2 3 1} & \mathbf{5 4 8 0} \\ 9.6 & 241 & 5380 \\ 5.3 & 239 & 5460 \\ 5.1 & 242 & 5610 \\ 6.4 & 223 & 5360 \\ 2.8 & 239 & 5570 \\ 3.5 & 238 & 5540 \\ 3.8 & 241 & 5330 \\ 1.8 & 246 & 5570 \\ <0.1 & 238 & 5310 \\ 1.1 & 243 & 5230 \\ 0.7 & 250 & 5230 \\ <0.1 & 245 & 5000 \\ \mathbf{3 0 . 8} & \mathbf{2 4 5} & \mathbf{5 0 4 0} \\ 1.1 & 245 & 5040 \\ 2.9 & 246 & 5120 \\ 1.2 & 242 & 5100 \\ 1.1 & 240 & 5020 \\ 2.8 & 245 & 5100 \\ 4.2 & 237 & 5120\end{array}$

Mg
38.6
30.0
28.8
112.6
38.6
29.0
43.7
31.1
41.0
32.3
35.1
27.7
27.9
25.8
47.3
89.3
49.6
36.5
48.7
59.2

$\mathrm{K}$

38.0

SO4

$<1.0$

$\mathrm{Cl}$ 4550

$\begin{array}{llll}59.2 & 48.0 & <1.0 & 4550\end{array}$




NA-001 FEED
NA-002
NA-003
NA-004
NA-005
NA-006
NA-007
NA-008
NA-009
NA-010
NA-011
NA-012
NA-013
NA-014 FEED
NA-015
NA-016
NA-017
NA-018
NA-019
NA-020

$\begin{array}{rrrrrrrr}\mathrm{Cr} & \mathrm{Mo} & \mathrm{Ni} & \mathrm{Pb} & \mathrm{Ag} & \mathrm{Hg} & \mathrm{Ba} & \mathrm{Cd} \\ <0.01 & <0.05 & <0.01 & <0.01 & \mathbf{0 . 1 8 3} & <0.0002 & <1.0 & \mathbf{0 . 0 8 0} \\ <0.01 & <0.05 & <0.01 & <0.01 & 0.000 & <0.0002 & <1.0 & 0.065 \\ <0.01 & <0.05 & <0.01 & <0.01 & 0.013 & <0.0002 & <1.0 & 0.065 \\ <0.01 & <0.05 & <0.01 & <0.01 & 0.034 & <0.0002 & <1.0 & 0.063 \\ <0.01 & <0.05 & <0.01 & <0.01 & 0.020 & <0.0002 & <1.0 & 0.065 \\ <0.01 & <0.05 & <0.01 & <0.01 & 0.028 & <0.0002 & <1.0 & 0.065 \\ <0.01 & <0.05 & <0.01 & <0.01 & 0.030 & <0.0002 & <1.0 & 0.065 \\ <0.01 & <0.05 & <0.01 & <0.01 & 0.033 & <0.0002 & <1.0 & 0.070 \\ <0.01 & <0.05 & <0.01 & <0.01 & 0.035 & <0.0002 & <1.0 & 0.065 \\ <0.01 & <0.05 & <0.01 & <0.01 & 0.043 & <0.0002 & <1.0 & 0.068 \\ <0.01 & <0.05 & <0.01 & <0.01 & 0.045 & <0.0002 & <1.0 & 0.068 \\ <0.01 & <0.05 & <0.01 & <0.01 & 0.050 & <0.0002 & <1.0 & 0.068 \\ <0.01 & <0.05 & <0.01 & <0.01 & 0.050 & <0.0002 & <1.0 & 0.068 \\ <0.01 & <0.05 & <0.01 & <0.01 & 0.053 & <0.0002 & <1.0 & \mathbf{0 . 0 6 8} \\ <0.01 & <0.05 & <0.01 & <0.01 & 0.058 & <0.0002 & <1.0 & 0.075 \\ <0.01 & <0.05 & <0.01 & <0.01 & 0.058 & <0.0002 & <1.0 & 0.068 \\ <0.01 & <0.05 & <0.01 & <0.01 & 0.050 & <0.0002 & <1.0 & 0.070 \\ <0.01 & <0.05 & <0.01 & <0.01 & 0.060 & <0.0002 & <1.0 & 0.068 \\ <0.01 & <0.05 & <0.01 & <0.01 & 0.065 & <0.0002 & <1.0 & 0.068 \\ <0.01 & <0.05 & <0.01 & <0.01 & 0.065 & <0.0002 & <1.0 & 0.068\end{array}$

NA-001 FEED
NA-002
NA-003
NA-004
NA-005
NA-006
NA-007
NA-008
NA-009
NA-010
NA-011
NA-012
NA-013
NA-014 FEED
NA-015
NA-016
NA-017
NA-018
NA-019
NA-020

\begin{tabular}{|c|c|c|c|c|c|c|}
\hline $\mathrm{CO} 3$ & TSS & $\mathrm{Zn}$ & $\mathrm{Fe}$ & $\mathrm{Mn}$ & $\mathrm{Cu}$ & $\mathrm{Al}$ \\
\hline 119 & 59 & 0.40 & 69.1 & 0.92 & 0.265 & $<0.1$ \\
\hline 108 & 19 & 0.55 & 77.9 & 0.93 & 0.050 & $<0.1$ \\
\hline 118 & 22 & 0.55 & 76.4 & 0.89 & 0.028 & $<0.1$ \\
\hline 119 & 15 & 0.44 & 75.3 & 0.88 & 0.033 & $<0.1$ \\
\hline 114 & 21 & 0.93 & 72.6 & 0.87 & 0.030 & $<0.1$ \\
\hline 114 & 14 & 0.94 & 73.9 & 0.87 & 0.035 & $<0.1$ \\
\hline 114 & 18 & 1.28 & 73.9 & 1.00 & 0.033 & $<0.1$ \\
\hline 119 & 13 & 1.10 & 72.5 & 0.96 & 0.043 & $<0.1$ \\
\hline 108 & 15 & 1.07 & 72.5 & 0.97 & 0.033 & $<0.1$ \\
\hline 114 & 25 & 0.90 & 71.4 & 1.00 & 0.033 & $<0.1$ \\
\hline 102 & 17 & 0.63 & 68.8 & 0.96 & 0.028 & $<0.1$ \\
\hline 102 & 19 & 0.90 & 71.0 & 0.90 & 0.023 & $<0.1$ \\
\hline 102 & 23 & 1.00 & 69.9 & 0.90 & 0.023 & $<0.1$ \\
\hline 108 & 20 & 1.16 & 69.9 & 0.95 & 0.043 & $<0.1$ \\
\hline 119 & 24 & 1.11 & 69.4 & 0.88 & 0.045 & $<0.1$ \\
\hline 114 & 19 & 1.28 & 69.8 & 0.89 & 0.035 & $<0.1$ \\
\hline 102 & 17 & 1.28 & 72.6 & 0.91 & 0.038 & $<0.1$ \\
\hline 91 & 25 & 1.10 & 72.6 & 0.89 & 0.043 & $<0.1$ \\
\hline 97 & 30 & 1.18 & 72.8 & 0.89 & 0.033 & $<0.1$ \\
\hline 97 & 18 & 1.19 & 72.6 & 0.90 & 0.035 & $<0.1$ \\
\hline
\end{tabular}




\section{Second Test Series Results Using Initial Column Filters}

Laboratory No. 4372

First Batch Of Produced Water

Date Sampled: 2/1-7/2001

Date Received: 2/13/01

\begin{tabular}{|c|c|c|c|c|c|c|}
\hline Sample ID & $\begin{array}{c}\text { ppb } \\
\text { Benzene }\end{array}$ & Toluene & Ethylbenzene & M,p-Xylene & o-Xylene & $\begin{array}{c}\text { ppm } \\
\text { Oil \& Grease } \\
\end{array}$ \\
\hline 01-Feb I & 100 & 121 & 4.5 & 23.4 & 12.3 & 182 \\
\hline 01-Feb O & 35.5 & 46.2 & 6.5 & 8 & 2.4 & 117 \\
\hline 02-Feb I & 404 & 583 & 8.7 & 118 & 50.9 & 106 \\
\hline 02-Feb O & 603 & 707 & 7.6 & 109 & 48.9 & 79.2 \\
\hline 05-Feb I & 499 & 602 & 7.4 & 101 & 45.4 & 100 \\
\hline 05-Feb O & 517 & 501 & 55.2 & 69 & 35.1 & 42 \\
\hline 06-Feb I & 651 & 723 & 8.5 & 107 & 49.8 & 118 \\
\hline 06-Feb O & 357 & 414 & 4.5 & 70.8 & 34.2 & 15.7 \\
\hline
\end{tabular}

Laboratory No. 4372

Second Batch Of Produced Water

Date Sampled: 2/7-12/2001

Date Received: 2/13/01

\begin{tabular}{crrrrrr}
\multicolumn{2}{c}{$\begin{array}{c}\mathrm{ppb} \\
\text { Sample ID }\end{array}$} & \multicolumn{1}{c}{ Toluene } & Ethylbenzene & M,p-Xylene & o-Xylene & Oil \& Grease \\
\hline 07-Feb I & 448 & 368 & 24.1 & 174 & 81.8 & 258 \\
07-Feb O & 362 & 225 & 6.6 & 51.6 & 25.4 & 403 \\
07-Feb I & 493 & 429 & 26.2 & 186 & 79.6 & 179 \\
07-Feb O & 466 & 296 & 10.6 & 73.6 & 37.2 & 140 \\
08-Feb I & 1530 & 1140 & 63.4 & 302 & 126 & 255 \\
08-Feb O & 916 & 670 & 32.7 & 201 & 87.6 & 239 \\
09-Feb I & 624 & 360 & 14 & 87.8 & 42.8 & 276 \\
09-Feb O & 1350 & 865 & 30.2 & 189 & 87.9 & 251 \\
12-Feb I & 2010 & 1260 & 47.2 & 306 & 134 & 175 \\
12-Feb O & 1300 & 847 & 28.4 & 182 & 83.4 & 141
\end{tabular}

Laboratory No. 4383

Third Batch Of Produced Water

Date Sampled: 2/13-20/2001

Date Received: 2/22/01

\begin{tabular}{|c|c|c|c|c|c|c|}
\hline Sample ID & $\begin{array}{c}\text { ppb } \\
\text { Benzene }\end{array}$ & Toluene & Ethylbenzene & M,p-Xylene & o-Xylene & $\begin{array}{c}\text { ppm } \\
\text { Oil \& Grease } \\
\end{array}$ \\
\hline 13-Feb I & 1260 & 424 & 9.9 & 66.8 & 35.6 & 12 \\
\hline 13-Feb O & 1330 & 538 & 8.9 & 66.6 & 32.8 & 17. \\
\hline 13-Feb I & 1950 & 832 & 13.6 & 111 & 51.9 & 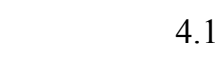 \\
\hline 13-Feb O & 1890 & 745 & 10.9 & 85.2 & 41.7 & 8.3 \\
\hline 14-Feb I & 1470 & 617 & 10.5 & 81.4 & 39.1 & 4.2 \\
\hline 14-Feb O & 2740 & 1280 & 22.2 & 172 & 78.6 & \\
\hline 19-Feb I & 4150 & 2720 & 55.7 & 471 & 190 & 4.3 \\
\hline 19-Feb O & 4560 & 2640 & 50.1 & 422 & 181 & 8.2 \\
\hline $20-F e b \quad$ I & 4240 & 2770 & 57.9 & 484 & 197 & 2 \\
\hline $20-F e b \mathrm{O}$ & 4010 & 2540 & 50.5 & 424 & 178 & \\
\hline
\end{tabular}

